\title{
The effect of acromioclavicular joint degeneration on orthopedic shoulder tests
}

\author{
Akromiyoklaviküler eklem dejenerasyonunun ortopedik omuz testleri üzerine etkisi
}

\author{
Alper Murat Ulaşlı, M.D.,, Serap Erkeç, M.D.,, ${ }^{2}$ Seçil Uyar, M.D., ${ }^{2}$ Barış Nacır, M.D., ${ }^{2}$ \\ Ömer Yılmaz, M.D., ${ }^{3}$ Hatice Rana Erdem, M.D. ${ }^{2}$ \\ 1Department of Physical Medicine and Rehabilitation, Medicine Faculty of Afyon Kocatepe University, Afyon, Turkey \\ 2Department of Physical Medicine and Rehabilitation, Ankara Training and Research Hospital, Ankara, Turkey \\ ${ }^{3}$ Department of Radiology, Ankara Training and Research Hospital, Ankara, Turkey
}

\begin{abstract}
Objectives: This study aims to investigate the effect of acromioclavicular joint (ACJ) degeneration on orthopedic shoulder tests (OST) and to determine complementary role of ACJ injections in the treatment of subacromial shoulder impingements.
\end{abstract}

Patients and methods: At a secondary care center, 62 patients (56 females, 6 males; mean age $55.8 \pm 9.3$ years; range 35 to 74 years) with the clinical and radiological diagnosis of shoulder impingement syndrome were enrolled to the study. Two injections were applied to ACJ and subacromial space. Patients were assessed through OSTs (Neer, HawkinsKennedy, empty can, full can, external rotation resistance, lift-off and cross-body adduction tests) at baseline and after injection to ACJ and subacromial space. Visual analog scale was used for overall pain.

Results: Two injections and three sets of OSTs were performed on the patients. A significant difference was found in the all OSTs after ACJ injection $(\mathrm{p}<0.001)$. Visual analog scale scores improved significantly following both ACJ and subacromial injections $(\mathrm{p}<0.001)$.

Conclusion: Concomitant ACJ diseases should assessed carefully in the patients with rotator cuff lesions, as it may change the type of management approach.

Key words: Acromioclavicular joint; injection; intraarticular; shoulder impingement syndrome; shoulder pain.

Physical examination of shoulder diseases remains a debate for clinicians because of questions about reliability of orthopedic shoulder tests (OST). Various studies concerning the diagnostic accuracy and reliability of OSTs with different methodologies have
Amaç: Bu çalışmada akromiyoklaviküler eklem (AKE) dejenerasyonunun ortopedik omuz testleri (OOT) üzerine etkisi araştırıldı ve AKE enjeksiyonlarının omuz sıkışma tedavisindeki tamamlayıcı rolü belirlendi.

Hastalar ve yöntemler: İkinci basamak bir hastanede, klinik ve radyolojik olarak omuz sıkışma sendromu tanısı konulan 62 hasta (56 kadın, 6 erkek; ort. yaş $55.8 \pm 9.3$ yıl; dağılım 35-74 yıl) çalışmaya alındı. Akromiyoklaviküler eklem ve subakromiyal bölgeye iki enjeksiyon yapıldı. Hastalar başlangıçta ve AKE ve subakromiyal enjeksiyondan sonra OOT'ler ile (Neer, Hawkins-Kennedy, empty can, full can, eksternal rotasyon direnç, lift-off ve cross-body adduksiyon testleri) değerlendirildi. Genel ağrı skoru için görsel analog ölçeği kullanıldı.

Bulgular: Hastalara iki kez enjeksiyon ve üç kez de OOT uygulandı. Akromiyoklaviküler eklem enjeksiyonu sonrası OOT'nin tamamında anlamlı bir farklılık saptandı $(\mathrm{p}<0.001)$. Hem AKE hem de subakromial enjeksiyon sonrasında görsel analog ölçeği skorlarında anlamlı düzelme saptandı $(\mathrm{p}<0.001)$.

Sonuç: Rotatör kılıf lezyonu olan hastalarda, hastaya uygulanacak tedavi yaklaşımını değiştirebileceğinden, eşlik eden AKE hastalıkları dikkatle değerlendirilmelidir.

Anahtar sözcükler: Akromiyoklaviküler eklem; enjeksiyon; intraartiküler; omuz sıkışma sendromu; omuz ağrısı.

been published. ${ }^{[1-3]}$ In a comprehensive review by Hegedus et al., ${ }^{[1]}$ most of the clinical examination tests for shoulder diseases were found to have limited diagnostic value. The main problem seems to be limited ability of tests to address the source of pain.

- Received: April 04, 2012 Accepted: March 01, 2013

- Correspondence: Alper Murat Ulaşlı, M.D. Afyon Kocatepe Üniversitesi Tıp Fakültesi Fiziksel Tıp ve Rehabilitasyon Anabilim Dalı, 03200 Afyon, Turkey. Tel: +90 505 - 3073648 Fax: +90 272 - 2463322 e-mail: alperulasli@yahoo.com 
Although acromioclavicular joint (ACJ) diseases frequently accompany shoulder diseases, the possible confounding effect of ACJ degeneration on OSTs have not been evaluated before.

Current options for treatment of shoulder impingement include physical therapy, corticosteroid injections or surgery. ${ }^{[4,5]}$ The ability to correctly diagnose the source of shoulder pain can avoid further unnecessary diagnostic procedures which are mostly more expensive and time consuming. ${ }^{[6]}$ In this regard, it is important to clarify underlying pathology for accurate management. The aim of this study was twofold; first, to investigate whether ACJ diseases affect OSTs, second to determine complementary role of ACJ injections in treatment of subacromial shoulder impingements.

\section{PATIENTS AND METHODS}

This prospective observational study was conducted in the Ankara Education and Research Hospital, $2^{\text {nd }}$ Department of Physical Medicine and Rehabilitation, between April and September 2010. Approval for the study was gained from the local research ethics committee of the hospital.

Sixty-two patients (56 females, 6 males; mean age $55.8 \pm 9.3$ years, range 35 to 74 years) with shoulder pain for at least four weeks and pain on palpation of the ACJ with the ability to follow instructions were included in the study. All patients filled an informed consent form. All of the patients were diagnosed with shoulder impingement syndrome and acromioclavicular degeneration by ultrasonography (US) or magnetic resonance imaging (MRI). Patients with local skin infections, history of malignancy and platelet dysfunction or bleeding disorder, history of corticosteroid injection to shoulder within two months were excluded from the study.

Each patient was examined by the same physiatrist who was experienced in OSTs and performed the tests in same order. The OSTs were classified as: tests evaluating subacromial impingement (Neer test and Hawkins-Kennedy test), tests evaluating rotator cuff tendons (empty can and full can tests for supraspinatus, external rotation resistance test for infraspinatus, liftoff test for subscapularis) and test evaluating $\mathrm{ACJ}$ (cross-body adduction test).

The Neer test was performed with the examiner stabilizing the ipsilateral scapula with fully flexing and elevating the humerus overhead maximally. ${ }^{[7]}$ Originally, a positive test was reproduction of shoulder pain, but to determine the intensity of the pain, we scored the pain as severe, mild or absent. The second test was the Hawkins-Kennedy test in which the arm was placed in 90 degrees of forward flexion and then maximally rotated to internal rotation. A positive test was reproduction of pain of the shoulder. ${ }^{[8]}$ Similarly, the pain was scored as severe, mild or absent.

The empty can test which was also known as supraspinatus muscle strength test or Jobe test, was performed by the examiner elevating the shoulder to 90 degrees, approximately 30 degrees anterior to the coronal plane with the arm internally rotated and the patient's thumb pointing to the floor. The examiner applied pressure to the wrist while the patient was attempting to resist. ${ }^{[9]}$ The test was considered positive if pain or weakness was observed. The full can test was performed similarly, but the thumb was pointing upwards. ${ }^{[10]}$ We scored pain in these two tests in the same manner, to determine the possible overload to the ACJ during these maneuvers as well as response to injections.

Placing the arm at the patient's side and flexing their elbow to 90 degrees performed the external rotation resistance test. The patient attempted to resist the force applied on the posterior aspect of the distal forearm by the examiner ${ }^{[11]} \mathrm{A}$ positive test was considered if pain or weakness was detected in the involved shoulder.

The lift-off test was performed while the patients were standing with their hand behind their back with the dorsum of the hand facing the mid-lumbar region. The dorsum of the hand was raised off the back by maintaining or increasing internal rotation of the humerus and extension at the shoulder. ${ }^{[12]}$ The test was considered positive if weakness was detected. The intensity of pain was scored as above. The cross-body adduction test was performed with the arm placed in 90 degree forward flexion and then was adducted across the trunk by the examiner. A positive test was considered if pain was detected in the shoulder. ${ }^{[13]}$

First, all patients were examined with OSTs and the first injection of $0.5 \mathrm{ml}$ prilocaine was administered into the acromioclavicular joint. Fifteen minutes later, patients were re-examined with OSTs and the second injection containing $20 \mathrm{mg}$ methylprednisolone and $1 \mathrm{ml}$ prilocaine was delivered into the subacromial space via posterolateral approach. The last set of OSTs was performed 15 minutes after the second shot.

\section{Statistical analysis}

For statistical analysis SPSS version 15.0 for Windows (SPSS Inc. Chicago, Illinois, USA) was used. To determine the difference before and after injections for cross-body adduction test, the McNemar's test was used. For the rest of the OSTs, two related samples 
TABLE I

The intensity of pain before and after injections and the significance of the difference for the tests evaluating subacromial impingement

\begin{tabular}{|c|c|c|c|c|c|c|c|c|}
\hline & \multicolumn{2}{|c|}{ Initial examination } & \multicolumn{2}{|c|}{ After ACJI } & \multirow[b]{2}{*}{$p$} & \multicolumn{2}{|c|}{ After SAI } & \multirow[b]{2}{*}{$p$} \\
\hline & $\mathrm{n}$ & $\%$ & $\mathrm{n}$ & $\%$ & & $\mathrm{n}$ & $\%$ & \\
\hline \multicolumn{9}{|l|}{ Neer test } \\
\hline Negative & 2 & 3.2 & 12 & 19.4 & \multirow{3}{*}{$<0.001$} & 42 & 67.7 & \multirow{3}{*}{$<0.001$} \\
\hline Mild & 23 & 37.1 & 37 & 59.7 & & 19 & 30.6 & \\
\hline Severe & 37 & 59.7 & 13 & 21.0 & & 1 & 01.6 & \\
\hline \multicolumn{9}{|c|}{ Hawkins-Kennedy test } \\
\hline Negative & 4 & 9.1 & 6 & 9.7 & \multirow{3}{*}{$<0.001$} & 19 & 30.6 & \multirow{3}{*}{$<0.001$} \\
\hline Mild & 29 & 45.5 & 30 & 48.4 & & 36 & 58.1 & \\
\hline Severe & 29 & 45.5 & 26 & 41.9 & & 7 & 11.3 & \\
\hline
\end{tabular}

ACJ: Acromioclavicular joint injection; SAI: Subacromial injection.

Wilcoxon signed ranks test were used. Student t-test was used to evaluate the difference between visual analog scale (VAS) scores. Significance was determined at the $5 \%$ level.

\section{RESULTS}

Twenty patients were suffering from left sided (32\%) shoulder pain, whereas 42 of them had right-sided shoulder pain (68\%). Thirty-eight patients $(61 \%)$ were evaluated with MRI and 24 patients (39\%) were evaluated with US. As the aim of this study was to assess the contribution of ACJ degeneration on OST results instead of evaluating sensitivity or specificity levels of each test for specific shoulder disorder, we did not include pathologies detected by two imaging modalities for analysis.

Initially, mean VAS score of the patients was $67.9 \pm 8.3$, it was decreased to $50.2 \pm 9.0$ after ACJ injection and to $25.5 \pm 10.8$ after subacromial injection (SAI). The improvement in VAS scores was significant after both of the injections $(\mathrm{p}<0.001)$. The ACJ injections seemed to affect all OSTs evaluating shoulder impingement,

\section{TABLE II}

The intensity of pain before and after injections and the significance level of the difference for the tests evaluating rotator cuff

\begin{tabular}{|c|c|c|c|c|c|c|c|c|}
\hline & \multicolumn{2}{|c|}{ Initial examination } & \multicolumn{2}{|c|}{ After ACJI } & \multirow[b]{2}{*}{$p$} & \multicolumn{2}{|c|}{ After SAI } & \multirow[b]{2}{*}{$p$} \\
\hline & $\mathrm{n}$ & $\%$ & $n$ & $\%$ & & $\mathrm{n}$ & $\%$ & \\
\hline \multicolumn{9}{|l|}{ Empty can test } \\
\hline Severe & 32 & 51.6 & 8 & 12.9 & \multirow{3}{*}{$<0.001$} & 1 & 1.6 & \multirow{3}{*}{$<0.001$} \\
\hline Mild & 29 & 46.8 & 38 & 61.3 & & 13 & 21.0 & \\
\hline Negative & 1 & 1.6 & 16 & 25.8 & & 48 & 77.4 & \\
\hline \multicolumn{9}{|l|}{ Full can test } \\
\hline Severe & 32 & 51.6 & 8 & 12.9 & \multirow{3}{*}{$<0.001$} & 1 & 1.6 & \multirow{3}{*}{$<0.001$} \\
\hline Mild & 29 & 46.8 & 42 & 67.7 & & 19 & 30.6 & \\
\hline Negative & 1 & 1.6 & 12 & 19.4 & & 42 & 67.7 & \\
\hline \multicolumn{9}{|l|}{ ERRT } \\
\hline Severe & 15 & 24.2 & 1 & 1.6 & \multirow{3}{*}{$<0.001$} & 0 & 0 & \multirow{3}{*}{$<0.001$} \\
\hline Mild & 38 & 61.3 & 39 & 62.9 & & 16 & 44.1 & \\
\hline Negative & 9 & 14.5 & 22 & 35.5 & & 46 & 69.3 & \\
\hline \multicolumn{9}{|l|}{ Lift-off } \\
\hline Severe & 15 & 24.2 & 6 & 9.7 & \multirow{4}{*}{$<0.001$} & 1 & 1.6 & \multirow{4}{*}{$<0.001$} \\
\hline Mild & 26 & 41.9 & 34 & 52.8 & & 24 & 38.7 & \\
\hline Negative & 5 & 8.1 & 13 & 21.0 & & 30 & 48.4 & \\
\hline Not able to & 16 & 25.8 & 9 & 14.5 & & 7 & 11.3 & \\
\hline
\end{tabular}

ACJI: Acromioclavicular joint injection; SAI: Subacromial injection; ERRT: External rotation resistance test; Not able to: Not able to perform the test because of pain or severe impingement. 
TABLE III

The intensity of pain before and after injections and the significance level of the difference between cross-body adduction test results

\begin{tabular}{|c|c|c|c|c|c|c|c|c|}
\hline & \multicolumn{2}{|c|}{ Initial examination } & \multicolumn{2}{|c|}{ After ACJI } & \multirow[b]{2}{*}{$p$} & \multicolumn{2}{|c|}{ After SAI } & \multirow[b]{2}{*}{$p$} \\
\hline & $\mathrm{n}$ & $\%$ & $\mathrm{n}$ & $\%$ & & $\mathrm{n}$ & $\%$ & \\
\hline \multicolumn{9}{|l|}{ Cross-body } \\
\hline Negative & 6 & 9.7 & 34 & 54.8 & & 56 & 90.3 & \\
\hline Mild & 48 & 77.4 & 28 & 45.2 & $<0.001$ & 6 & 9.7 & $<0.001$ \\
\hline Severe & 8 & 12.9 & 0 & 0 & & 0 & 0 & \\
\hline
\end{tabular}

ACJI: Acromioclavicular joint injection; SAI: Subacromial injection.

rotator cuff lesions and ACJ with a significance level of $\mathrm{p}<0.001$ for all. The effect of ACJ and SAIs on each class of OST results is demonstrated in Table I-III.

On initial examination, 16 patients $(26 \%)$ were not able to perform the lift-off test, however seven of them could perform the lift-off test after ACJ injections while two additional patients could perform the lift-off test after SAI.

An interesting result to be noted was that in 28 of 48 patients, the cross-body adduction test was still positive even after ACJ injection but after SAI 22 of these 28 patients' pain during cross-body adduction test was resolved.

\section{DISCUSSION}

Together with detailed history, inspection, palpation and detection of active and passive ranges of motion, OSTs serve as a key step in the clinical assessment of the painful shoulder. ${ }^{[14]}$ The main findings of the present study are the influence of OST results by ACJ diseases and the determination of significant improvement in overall pain score with ACJ injection. Tests for subscapularis tendinopathy often cause pain, in common with subacromial impingement tests, because they require marked internal rotation. ${ }^{[14]}$ An interesting result of the current study was the ability of some patients to perform lift-off test after ACJ injection when they were not able to do so on initial examination. The load on the ACJ can explain this during internal rotation and adduction which may cause pain and result with a false positive test.

Another interesting result of the study was that the cross-body adduction test was positive in some of the patients even after ACJ injection but pain resolution was observed in a significant number of these patients after SAI. This observation might be explained by impingement of the subscapularis or anterior part of supraspinatus during flexion and partial internal rotation resulting with pain during the test. ${ }^{[15]}$
Roidis et al., ${ }^{[16]}$ studied the influence of acromioclavicular joint degeneration on supraspinatus outlet impingement and emphasized the importance of acromioclavicular joint evaluation, because its degeneration may affect the magnitude of encroachment. Acromioclavicular joint injection may increase the specificity values of clinical tests and may direct the surgeon about the type of surgery and can be able to prevent unresolved pain after rotator cuff surgery. ${ }^{[17]}$

The utility of the tests in different degrees of impingement was evaluated before by confirming with ultrasonography and surgery. ${ }^{[18,19]}$ A limitation of this study was that we did not analyze the effect of injections in separate impingement degrees and/or specific shoulder disease conditions.

In conclusion, the ACJ diseases should be taken into consideration in the assessment of patients with symptoms of rotator cuff diseases as they may influence OST results. Thus, ACJ injections may be considered for either pain relief or to increase diagnostic accuracy of OST's especially in patients with ACJ degeneration.

\section{Declaration of conflicting interests}

The authors declared no conflicts of interest with respect to the authorship and/or publication of this article.

\section{Funding}

The authors received no financial support for the research and/or authorship of this article.

\section{REFERENCES}

1. Hegedus EJ, Goode A, Campbell S, Morin A, Tamaddoni M, Moorman CT 3rd, et al. Physical examination tests of the shoulder: a systematic review with meta-analysis of individual tests. Br J Sports Med 2008;42:80-92.

2. Park HB, Yokota A, Gill HS, El Rassi G, McFarland EG. Diagnostic accuracy of clinical tests for the different degrees of subacromial impingement syndrome. J Bone 
Joint Surg Am 2005;87:1446-55.

3. Caliş M, Akgün K, Birtane M, Karacan I, Caliş H, Tüzün F. Diagnostic values of clinical diagnostic tests in subacromial impingement syndrome. Ann Rheum Dis 2000;59:44-7.

4. Kesmezacar H, Erginer R, Babacan M, Oğut T, Yucel B. The role of acromioplasty in the treatment of subacromial impingement syndrome. Eklem Hastalik Cerrahisi 2004;15:129-34.

5. Yılmaz C, Gölpınar A, Oztuna V. The efficacy of subacromial corticosteroid injections in impingement syndrome. Eklem Hastalik Cerrahisi 2008;19:24-6.

6. Walton J, Mahajan S, Paxinos A, Marshall J, Bryant C, Shnier $\mathrm{R}$, et al. Diagnostic values of tests for acromioclavicular joint pain. J Bone Joint Surg [Am] 2004;86:807-12.

7. Neer CS 2nd. Impingement lesions. Clin Orthop Relat Res 1983;183:70-7.

8. Hawkins RJ, Kennedy JC. Impingement syndrome in athletes. Am J Sports Med 1980;8:151-8.

9. Jobe FW, Jobe CM. Painful athletic injuries of the shoulder. Clin Orthop Relat Res 1983;173:117-24.

10. Kelly BT, Kadrmas WR, Speer KP. The manual muscle examination for rotator cuff strength. An electromyographic investigation. Am J Sports Med 1996;24:581-8.

11. Clarkson H. Assessment process: the shoulder complex. In: Clarkson $\mathrm{H}$, editor. Musculoskeletal assessment: joint range of motion and manual muscle strength. Baltimore: Lippincott Williams \& Wilkins; 2000. p. 146-55.
12. Gerber C, Krushell RJ. Isolated rupture of the tendon of the subscapularis muscle. Clinical features in 16 cases. J Bone Joint Surg [Br] 1991;73:389-94.

13. McLaughlin HL. On the frozen shoulder. Bull Hosp Joint Dis 1951;12:383-93.

14. Clinical practice guidelines. Management of chronic painful shoulder without instability in adults. Available from: http://www.has-sante.fr [Accessed 2005].

15. Hughes PC, Green RA, Taylor NF. Measurement of subacromial impingement of the rotator cuff. J Sci Med Sport 2012;15:2-7. doi: 10.1016/j.jsams.2011.07.001.

16. Roidis NT, Motamed S, Vaishnav S, Ebramzadeh E, Karachalios TS, Itamura JM. The influence of the acromioclavicular joint degeneration on supraspinatus outlet impingement and the acromion shape. J Orthop Surg (Hong Kong) 2009;17:331-4.

17. Dayıcan A, Öztürk C, Portakal S, Özkan G, Cılız A, Özkurt B. The results of anterior acromioplasty for the treatment of the impingement syndrome in the shoulder. Eklem Hastalık Cerrahisi 2002;13:73-7.

18. Kelly SM, Brittle N, Allen GM. The value of physical tests for subacromial impingement syndrome: a study of diagnostic accuracy. Clin Rehabil 2010;24:149-58. doi: 10.1177/0269215509346103.

19. Park HB, Yokota A, Gill HS, El Rassi G, McFarland EG. Diagnostic accuracy of clinical tests for the different degrees of subacromial impingement syndrome. J Bone Joint Surg [Am] 2005;87:1446-55. 